43.

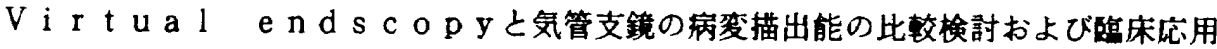

Clinical Application of Vitual Endscopy and the Comparative Study of the lesion Visibilty VS Bronchoscopy

慶応莪塾大学病院 中央放射線技術室 ○杉山典昭 直井貫宣 宮川幸三 清水正勝

【目的・方法】

近年、ヘリカルCTで得られた三次元画像を利用したVitual endscopyの侮床的有用性が検討されている。 今回、私たちは、気管内及び気管支内病変に、見立てた自作ファントムを作成し、Vitual endscopyと気管支鏡とで、 同一視点に於ける病変の描出能を比較検討した。

更にその結果を踏まえ臨床応用を行った。

使用機器 GE-YMS 社製H iSpeed Advantage SP、ワークステーションADVANTAGE VINDONS

【結果・考察】

Vitual endscopyと気管支鏡の視野の運いによる描出能の差はあるが、ほぼ同様の結果が得られた。 気管内及び気管支内腫崲の患者にVitual endscopyを用いて観察することは、韭侵軗的であり有用と思われる。

\title{
44. CT検査におけるガントリ傾斜角度の影每
}

Effect of gantry angle in computed tomography 大阪市立大学医学部附属病院中央放射線部

\section{○花岡信子 白石䐓二 宇都宮あかね 上田容子} 津田和良

（目的）CT検査において,ガントリを傾斜させてスキャンを行った場合,テーブル進む方向とスキャン断面が垂直 にならないために、同じテーブル送り距離を用いた場合には,スライス間隔が变化する.今回,われわれはこの影䍹に ついて幾何学的に検討し,人体ファントムによって䠛床的な評価を行った。

（方法）CT装監はSIEMENS社製 SOMATOM PLUS-S,東芝社製 X-Vigorを使用した.ガントリ傾斜角度と同一テーフ ル送り距離を用いた場合のスライス間隔の関係を計算上求め,その結果を元に,人体ファントムを用いて,頭部CT娭 査におけろスライス数と画像の位相について,ガントリを傾斜させない場合と,傾斜させた場合で比較した.また,人 体ファントムの水晶体の位置における被曝線量をTLDを用いて测定し,比較した。

(結果および考察) ガントリを傾斜させた場合には,その角度に応じてテーブル送り距離を設定する必要がある事 が計算上明らかとなり，人体ファントムを用いた㯺床評価においても，それが実証された.また,最適なテーブル送り 距離で検査を行うことで,被曝線量も有意に隇少することが測定の結果,明らかとなった。

45.

ガントリー倾斜が螺旋 C T画像に及ぼす影需

Effect of tilted gantry in Helical CT image.

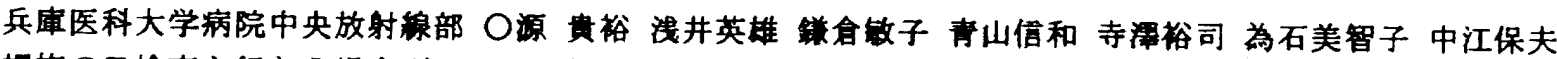

【目的】螺旋 CT検査を行なう場合ガントリー㑯斜を行なわずスキャンするのが通常である。しかし、春椎等の検

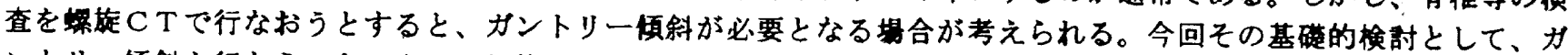
ントリー㑯斜を行なうことにより、罢旋CT画像にどのような影整を及ぼすのか検討を行なったので報告する。

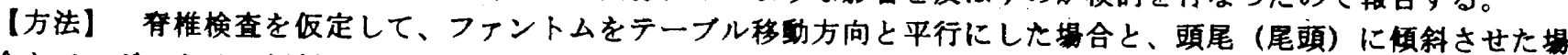

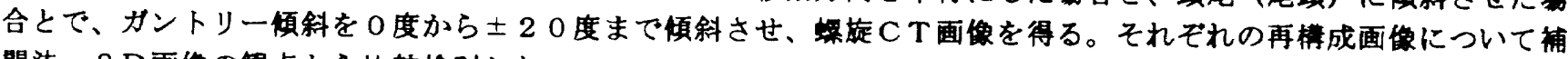
間法・3 D画像の観点から比慗検时した。

【結果・考察】カントリー㑯斜を行なった場合、ファントムがテーブル移勒方向と平行であれは、管球の回転中心 はファントムの中心と同じであるため、補間の影敕は受けない。しかし、ファントムが㑯斜すると、管球回転中心と ファントムの中心がずれ、補間時に前後のスライスでの㭪間位置にズレが生じる。これらのことにより、姆旋CTを 行なう場合、ガントリーを㑯斜することは問題とならす、テーブル移勒方向（体軸方向）に対するファントムとの㑯

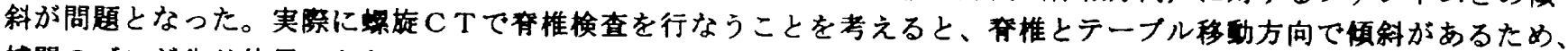
㭪間のズレが生じ使用できない。しかし、このズレをソフト面又はハード面で補正することができれば使用可能と考 える。 